Article

\title{
Estimating the Isotopic Altitude Gradient for Hydrogeological Studies in Mountainous Areas: Are the Low-Yield Springs Suitable? Insights from the Northern Apennines of Italy
}

\author{
Alberto Tazioli ${ }^{1, *(\mathbb{D}}$, Federico Cervi ${ }^{2} \mathbb{D}$, Marco Doveri $^{3}{ }^{(\mathbb{D}}$, Mario Mussi $^{3}$, Manuela Deiana ${ }^{4}$ and \\ Francesco Ronchetti ${ }^{4}$ \\ 1 Department of Scienze e Ingegneria della Materia, dell'Ambiente ed Urbanistica, \\ Università Politecnica delle Marche, via Brecce Bianche, 12-60131 Ancona, Italy \\ 2 Scientific High School Aldo Moro, 42124 Reggio Emilia, Italy \\ 3 Institute of Geosciences and Earth Resource, National Research Council of Italy, Via G. Moruzzi 1, \\ 56124 Pisa, Italy \\ 4 Department of Chemical and Geological Sciences, University of Modena and Reggio Emilia, \\ via Giuseppe Campi, 103-41125 Modena, Italy \\ * Correspondence: a.tazioli@univpm.it
}

Received: 14 June 2019; Accepted: 22 August 2019; Published: 23 August 2019

check for updates

\begin{abstract}
Several prior studies investigated the use of stable isotopes of water in hydrogeological applications, most on a local scale and often involving the isotopic gradient (evaluated by exploiting the so-called altitude effect), calculated on the basis of rainwater isotopes. A few times, this gradient has been obtained using the stable isotopic contents of low-yield springs in a limited time series. Despite the fact that this method has been recognized by the hydrogeological community, marked differences have been observed with respect to the mean stable isotopes content of groundwater and rainwater. The present investigation compares the stable isotopic signatures of 23 low-yield springs discharging along two transects from the Tyrrhenian sea to the Po Plain of Italy, evaluates the different isotopic gradients and assesses their distribution in relation to some climatic and topographic conditions. Stable isotopes of water show that groundwater in the study area is recharged by precipitation and that the precipitation regime in the eastern portion of the study area is strongly controlled by a shadow effect caused by the Alps chain on the air masses from central Europe. Stable isotopes (in particular the $\delta^{18} \mathrm{O}$ and deuterium excess (d-excess) contents together with the obtained isotopic gradients) allow us to identify in the study area an opposite oriented orographic effect and a different provenance of the air masses. When the windward slope is located on the Tyrrhenian side, the precipitation shows a predominant oceanic origin; when the windward slope moves to the Adriatic side, the precipitation is characterized by a continental origin. The main results of this study confirm the usefulness of low-yield springs and the need for a highly detailed survey-scale hydrological investigation in the mountainous context.
\end{abstract}

Keywords: stable water isotopes; northern Apennines; mountainous aquifers; isotopic gradient; groundwater

\section{Introduction}

Over the last few decades, several studies involving stable isotopes of water have been performed worldwide, many with the principal aim of investigating the factors involved in the precipitation formation process [1-5]. In mountainous areas, precipitation (in the form of rain and snow) is the input 
into hydrological processes occurring at the soil surface (i.e., evapotranspiration, runoff and infiltration). In this context, isotopic fractionation seems to be a key factor in understanding of hydrological processes connected to the entire hydrological cycle with a particular focus on precipitations. Indeed, the so-called isotopic effects are all related to the distribution of the contents and changes of the composition of stable isotopes all over the world and at different times of the year. In hydrological investigations, fractionation is one of the most important properties of isotopes, and the isotopic composition of water vapor is modified during evaporation, freezing, condensation, and melting due to isotopic fractionation [6-8]. Usually, the Global Meteoric Water Line (GMWL) is used to depict the relationship between the $\delta^{2} \mathrm{H}$ and $\delta^{18} \mathrm{O}$ content in precipitations on a global scale $[9,10]$.

In regional or hillslope-scale studies, a local meteoric water line (LMWL) is typically plotted, using data from local sampling stations. The isotopic composition of rainfall is affected by the so-called isotopic effects [11]. These are mainly dependent on the temperature of cloud formation and are followed by isotopic fractionation. The seasonal effect is the fluctuation of isotopic content related to temperature change and it represents an important tool for investigating the hydrodynamic of aquifers [12]. The altitude effect (i.e., isotopic depletion with increasing elevation) is likely the most important property in hydrogeological studies; with this property, in fact, the recharge areas of springs and aquifers can be identified in both local and regional groundwater systems [13-15]. The continental effect is the depletion of isotopic values moving from the coast to inland areas; this is a crucial issue in large continental areas, but reduced effects may be observed in small regions. Moreover, latitude greatly affects isotopic values. Dansgaard identified the so-called amount effect: a depletion in isotopic values occurring with great amounts of rainfall, resulting in a lower isotopic content than expected [16]. The overall effect creates correlations between isotopic variations and the hydrological cycle on a global or regional scale.

However, changes in isotopic content can also affect water during infiltration in different soils [17-19]. Soils, rocks, and vegetation can indeed act as selective filters for rain water, smoothing the seasonal variation of the input precipitation or choosing which precipitation events infiltrate and recharge the groundwater, especially in areas characterised by preferential zones of infiltration [20].

Further modifications of the isotopic content can occur at the soil surface during different hydrological processes such as evaporation, evapotranspiration, sublimation and refreezing from the snowpack, and runoff. These processes can strongly modify the former isotopic composition of precipitations collected in the gauges and, ultimately, isotopic recharge in the aquifer (i.e., infiltration water) can be significantly different from the isotopic signature of precipitation [2]. For instance, evaporation and transpiration, which may occur before and during infiltration, can cause more depleted values than expected [21]. As a consequence, the general assumption that the average isotopic signature of infiltration waters is very similar to the weighted mean of rainfall is not valid in all situations. Hence, isotopic gradient based on rainfall data can be unsuitable for use in hydrogeological studies and lead to significant errors in evaluating the average recharge altitude of groundwater systems.

The evaluation of the recharge areas of aquifers mainly involves the altitude effect and is based upon the following: (a) the long-term sampling of precipitations, (b) the calculation of the isotopic gradient, and (c) in a few cases, the use of little springs as natural pluviometers [22-25]. Some authors have reported isotopic altitude gradients that are valid for Italy [26] or for selected areas [2,20,25,27-32]. A recent study indexed $\delta^{18} \mathrm{O}$ data collected by several authors along the entire Italian peninsula, thus updating a previous similar work $[4,26]$.

The above-mentioned studies mainly focused on precipitations and represent the bases for further calculation of recharge areas of groundwater. In most cases, the isotopic gradients were obtained by starting from rain gauges datasets, and thus, their further comparison with groundwater did not take into account possible hydrological processes occurring at the soil surface (and the consequent isotopic changes in infiltrative water). In some cases, the isotopic gradients were obtained from springs, thus taking into account hydrological processes occurring at the soil surface, but the area involved in the abovementioned studies was relatively small (between 25 and $100 \mathrm{~km}^{2}$ ) $[22,25,32]$. 
In light of this framework, in the present study we examine the isotopic signatures of local low-yield springs discharging from the northern Italian Apennines. These springs are roughly aligned along two 130-km-long hypothetical transects, which connect the Ligurian sea to the Po Plain (Figure 1). The patterns of the isotopic signatures and their altitudes were investigated on each main slope in order to verify the benefit of obtaining an isotopic gradient from groundwater. Few studies [23,33] have already highlighted a marked discrepancy between isotopic values in precipitations and those in groundwater (with groundwater characterized by slightly lower $\delta^{18} \mathrm{O}$ values) that cannot be fully explained by weighting with rainfall alone. For this reason, in the studied springs, there are further processes that lead to isotopic differentiation between precipitation and groundwater that are not only due to evapotranspiration, which usually changes the isotopic signature by inducing more enriched values.

Given our purpose of testing the suitability of isotopic values from selected springs rather than from pluviometers in order to estimate isotopic gradients in mountainous areas, 23 springs distributed along two transects and showing similar features (i.e., similarities among the aquifers they drain, with small basin of recharge and a relatively high rate of renewal) were analyzed over the last decade. Isotopic gradients were evaluated in each zone of the transects, as these zones are characterized by different exposures from the coast of the Ligurian sea to the Po Plain.

As such, the aim of this paper is to test the suitability of isotopic values from selected springs rather than pluviometers to estimate isotopic gradients in mountainous areas. Only the low-yield springs were considered in this study.

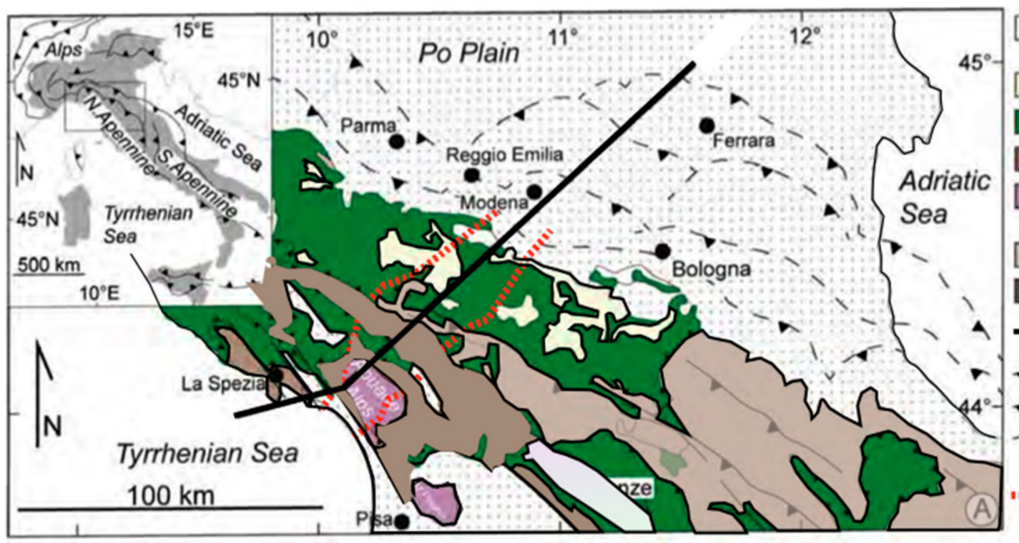

Neogene and Quaternary sediments

Epilugurian units

Ligurian units

Tuscan nappe

Metamorphic Tuscan units Tuscan Sedimentary, Sub-ligurian units

Tuscan basement

- Trace geological cross-section (B)

- Thrust and fault at surface

- Thrust and fault at subsurface

High angle normal faults and trascurrent faults

Trace cross-section (Isotope evaluation)

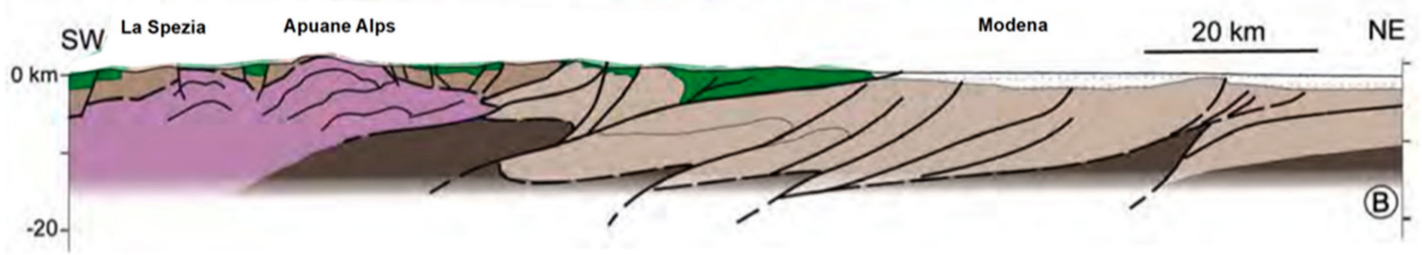

Figure 1. (A) Study area. (B) Simplified geological scheme and section (trace is represented by the black line), from [34], modified.

\section{Climatic, Geological and Hydrogeological Setting of the Study Area}

The study area is located in northern Italy and it extends over the Apennines range between the Ligurian coastline and the cities of Reggio Emilia and Modena, which are located on the western boundary of the Po Plain. The area encompasses around $2600 \mathrm{~km}^{2}$, and it extends for $83 \mathrm{~km}$ in the SW-NE direction and $32 \mathrm{~km}$ in the SE-NW direction and includes two main mountain ranges, the Apuan Alps and the Tuscany Emilian Apennines (Figure 2). 


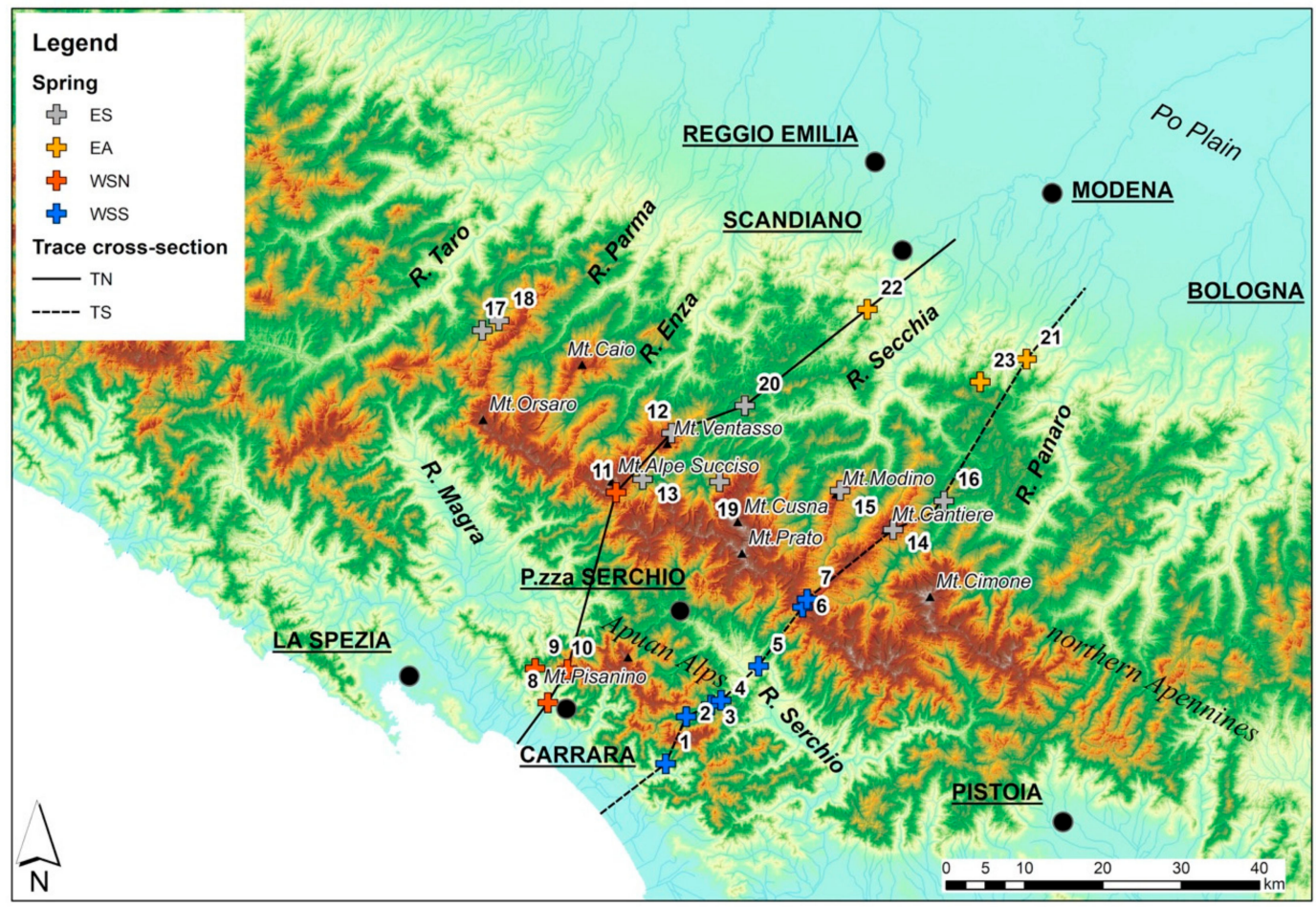

Figure 2. Location of the study area, indicating the altitudinal transects and the studied springs (see Table 1 for definition of the springs number). ES: eastern side spring; EA: eastern side Adriatic spring; WSN: western side spring (Northern transect); WSS: western side spring (Southern transect).

These two mountain complexes are parallel to one each other and are oriented SE-NW. They are separate by a graben in which the Serchio River flows. A simplified altimetry profile of the area, in the SW-NE direction, can be described as follow: starting from the Ligurian Tuscan coastline ( $0 \mathrm{~m}$ a.s.l.), the elevation gently increases (mean slope 3\%), reaching $200 \mathrm{~m}$ a.s.l. at Carrara city. Then, it abruptly increases (mean slope 20\%) up to the Mt. Pisanino, reaching $1945 \mathrm{~m}$ a.s.l., at the top of the Apuan Alps range. From here, the elevation rapidly decreases (mean slope 13\%) until it reaches $500 \mathrm{~m}$ a.s.l. at Piazza del Serchio. Then, the elevation again increases (mean slope 12\%) up to Mt. Prato (2053 $\mathrm{m}$ a.s.l.), which is located on the Apennines range. Eastward, the elevation gently decreases (mean slope 5\%), reaching $102 \mathrm{~m}$ a.s.l. at Scandiano, from which a lower slope (mean slope $<1 \%$ ) develops up to the cities of Reggio Emilia and Modena (about $50 \mathrm{~m}$ a.s.l.).

The area is crossed by valleys oriented about SE-NW and SW-NE on the Tuscany side and SW-NE on the Emilian side. The main rivers are the Serchio River and its tributaries, in the Tuscany side, and Secchia River and its tributaries on the Emilian side. The main reliefs in the area are the Mt. Pisanino (1945 m a.s.l.) and Piana della Croce (1858 m a.s.l.) on the Apuan Alps, the Alpe di Succiso (2017 m a.s.l.), Cima Belfiore (1810 m a.s.1.), and Mt. Prato (2053 m a.s.1.), which are located on the Apennines range, along the Tuscan-Emilian boundary, and Mt. Ventasso (1727 $\mathrm{m}$ a.s.l.), Mt. Cusna (2120 m a.s.1.), Mt. Modino (1414 m a.s.l.), Mt. Cantiere (1617 m a.s.l.), Pietra di Bismantova (1041 m a.s.l.), and Mt. Valestra (935 m a.s.l.), which are located on the Emilian side of the Apennines.

The amount of annual rainfall is correlated with the altitude and it is also affected by the local morphology and the distance from the sea. In the Po Plain and in the Tuscany coastal plain, the rainfall is around 700 and $1000 \mathrm{~mm}$ per year, respectively. In the Apuan Alps range the yearly rainfall is around $2500 \mathrm{~mm}$ in average [35], and in the zones close to the major ranges, rainfall reaches over $3000 \mathrm{~mm}$ per year [36]. Along the main Emilian reliefs, it is between 1600 and $2200 \mathrm{~mm}$ per year [37]. Generally, the autumn and spring seasons are characterized by wet conditions. The winter and early spring seasons are characterized by snowfall events, which are frequent at the highest mountain peaks of the Apennines but are more exceptional in the Apuan Alps. The summer season is characterized by rain 
showers in the mountain areas and by prolonged dry periods in the plains. The distribution of the mean annual temperature is inversely correlated with altitude, and subsequently, it depends on the local morphology, slope aspect, and the distance from the sea. The main annual temperature is around $14{ }^{\circ} \mathrm{C}$ near the coastline and around $5{ }^{\circ} \mathrm{C}$ at the highest mountain peaks. The origin of precipitations in the study area depends on the season and the position with respect to the Apennines range [38,39]. In winter, the contribution of continental air (from the north) is dominant with a small supply from the Adriatic Sea (from the east); in summer and the intermediate seasons, precipitations come from the Tyrrhenian sea and often reach as far as the central part of the Apennines range.

From a geological point of view, the northern Apennines are a fold-and-thrust mountain belt generated by the closure of the Liguria-Piemonte Ocean basin and the subsequent collision of the Adria and European continental plates [34,40]. As a consequence of the polyphasic evolution of the accretionary wedge, this part of the northern Apennines is made up of the metamorphic sequence of the Apuan Alps (phyllites, metavolcanics, and metamorphic carbonatic rocks) and of several tectono-stratigraphic units of marine sedimentary rocks, many of which are turbidite sequences (flysch rock masses) and clayey chaotic deposits (clayshales, marls). The Apuan Alps range is a metamorphic core complex outcropping in a tectonic window of the northern Apennines cover nappe, which was overthrusted during the Apennines' orogeny [41]. The several tectono-stratigraphic units of marine sedimentary rocks are known as follows: the Apuan Alps unit; Tuscan Nappe; Ligurian units; sub-Ligurian unit; Sestola Vidiciatico unit and Epiligurian units (Figure 1). All the units, and consequently, all the different geological formations that compose them, are crossed by high and low angle faults and thrusts [42]. Moreover, the geology of the area is characterized by the presence of quaternary deposits. Along the slope, large landslides and scree slopes outcrop. Moraine deposits outcrop only around the highest reliefs. At the bottom of the valleys, alluvial deposits extend, such as alluvial fans, palustrine deposits, and gravel deposits.

The hydrogeological setting of the northern Apennines is dominated by medium-low to low permeability units (clay or marly geological formations), which in many cases are considered as to be aquitard or aquicludes [43-45]. The exceptions are the main aquifers of the region, which are hosted within the metamorphic dolostones and limestones of the Apuan Alps ("Grezzoni" and "Carrara Marbles" Fms.). The latter are drained by more than 80 springs with flow rates ranging from 10 to $1600 \mathrm{~L} / \mathrm{s}$ on average [12,46]. Other remarkable aquifer systems include gypsum rock masses in the Emilian Apennines [47] and the limestone and cherty limestone of the Tuscan Nappe [45]. In any case, such aquifers are uncommon, because most of the springs are fed by shallow and unconfined aquifers hosted within highly tectonized and fractured flysch rock masses and sandstones [48,49], especially if affected by deep gravitational mass movements [50]. There, a rather high permeability value is obtained due to the presence of closely spaced rock joints that are gradually opening towards the surface due to a reduction of the pressure load (Figure 3a). As a result, shallow groundwater develops and feeds a huge number of low-yield springs where the local groundwater tables cross the land surfaces. These springs are poorly mineralized and their mean annual discharges range between less than $1 \mathrm{~L} / \mathrm{s}$ and tens $\mathrm{L} / \mathrm{s}[43,46,49]$, showing remarkable variation during the year. In fact, flow rates closely follow the rainfall distribution during the year, with the maximum in spring (April-May) and the minimum flow rates in summer to the beginning of autumn (September-October). It is worth noting that all the low-yield springs almost completely renew their water every year from autumn to spring (i.e., the recharge period). They usually show a continuous decrease of discharge from spring to autumn - the so-called recession (or depletion) period [51]. During the recession period, flow-rates are fed only by the groundwater, as infiltration does not occur within the unsaturated zone, being that evapotranspiration processes are active (Figure 3b). Lastly, there are a few rare examples of deep, highly mineralized springs and thermal springs in the area, which are located in zones characterized by peculiar geological structures such as tectonic windows and regional thrusts [45,52]. 


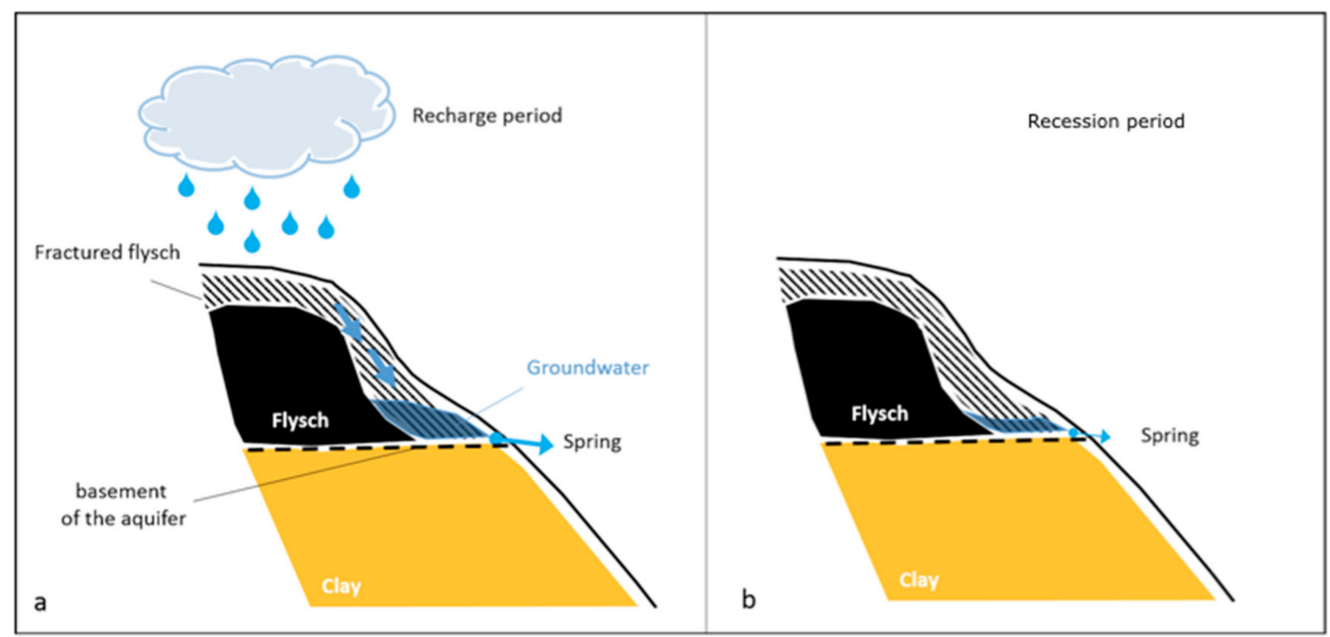

Figure 3. Simplified sketch of a low-yield spring discharging from the fractured zone of a flysch rock mass. (a) Recharge period (from winter to spring); (b) recession period (from the end of summer to the beginning of autumn). The arrows indicated by the spring are directly proportional to the discharge.

\section{Methods}

Considering the aims of this study, the 23 springs that were sampled were selected based on the following two criteria: (a) springs recharged by small and easily inferable basins, thus enabling us to estimate the average altitude of recharge, and (b) springs fed by shallow groundwater, likely representing water infiltrated over the last few years (1-5 years). Springs that fulfil both of these prerequisites can be defined as low-yield springs, in which a complete renewal of water takes place quickly [24].

The 23 selected springs are located along two transects (Figure 2) that start in the Ligurian coastline, cross the northern Apennines (at around at $1600 \mathrm{~m}$ a.s.l.), and gently decrease into the Po Plain (70 $\mathrm{m}$ a.s.1.). These two transects are represented by topographic and isotopic profiles, where the isotopic values are the arithmetic means of $\delta^{18} \mathrm{O}$ of springs collected during the recession period. Before crossing the main reliefs of the northern Apennines, both transects intersect the Apuan Alps (at about $1400 \mathrm{~m}$ a.s.l.), but only the southern transect crosses the large and depressed NW-SE valley through which the Serchio River flows. The total length of each transect is about $130 \mathrm{~km}$. In addition, a few other springs are located in the vicinity of the transects and were used to estimate the isotopic gradients. We selected these two different transects to better understand any possible influence caused by the Serchio valley, which, within a relatively short distance (about $40 \mathrm{~km}$ ), produces the two main ranges near the Ligurian sea (Figure 2), thus making possible the overlapping of different effects (mainly the altitude, continental and shadow effects) of isotopic fractionation.

This part of the Apennines is characterized by the widespread presence of perennial springs, whose discharges closely follow the inter-annual rainfall pattern, and which show a low average discharge, ranging between 0.5 and $2 \mathrm{~L} / \mathrm{s}$. Most of the selected springs drain groundwater flowing in pervasive networks of fractures within sandstones, small and not karstified carbonate bodies and flysches. Some of the springs are fed by slope deposits mainly lying above poor permeable bedrocks. As a result, most of the groundwater stored within the aquifers is renewed almost completely every hydrological year or over just a few years, and most of the springs reach the low-flow period at the end of summer or at the beginning of autumn.

The sampling of the springs was conducted during different seasons and years (from 2001 to 2016), especially in the recession period, when the precipitations did not have a big impact on the system since it did contribute little or nothing to the groundwater recharge. As shown in Figure 3, in this period only groundwater feeds the springs, as evapotranspiration processes are predominant rather than infiltration, and therefore, the isotopic value measured in this period can be considered to be an average of the entire seasonal recharge that occurs during the wet season. Samples were collected in Polyethylene bottles and then stored in the laboratory at $4{ }^{\circ} \mathrm{C}$. Isotopic analyses were performed via 
mass spectrometry at the Stable Isotopes Laboratory of the National Research Council (CNR-Pisa, Italy). The $\delta^{18} \mathrm{O}$ value was determined through the analysis of gaseous $\mathrm{CO}_{2}$, previously equilibrated with water at $25{ }^{\circ} \mathrm{C}$ with the use of a Finnigan MAT52. The mass-spectrometric measurement of the ${ }^{18} \mathrm{O} /{ }^{16} \mathrm{O}$ ratio requires correction because a fractionation between $\mathrm{CO}_{2}$ and $\mathrm{H}_{2} \mathrm{O}$ occurred [53]. It is widely accepted that all the isotopic results are expressed as permil based on the international measurement standard, the Vienna Standard Mean Ocean Water (V-SMOW) [6,9].

The analytical precision of the $\delta^{18} \mathrm{O} \%$ o values was better than $0.1 \%$. The $\delta^{2} \mathrm{H}$ value was measured with a Europa Scientific GEO 20-20 by reducing the water to elemental hydrogen using magnesium instead of zinc. Because the totality of water was reduced, and all the hydrogen was converted to hydrogen gas, the isotopic fractionation did not occur, and a correction of the mass-spectrometric measurement was not necessary. The analytical precision of the $\delta^{2} \mathrm{H}$ measurements was $1.5 \%$. The isotopic ratios of $\mathrm{CO}_{2}$ and $\mathrm{H}_{2}$ were measured by dual inlet mass spectrometer [54].

Starting from the $\delta^{18} \mathrm{O}$ and $\delta^{2} \mathrm{H}$ values, the deuterium-excess (d-excess; [16]) was calculated for each sample as follows:

$$
\text { d-excess }(\% \text { o })=\delta^{2} \mathrm{H}-8 \delta^{18} \mathrm{O}
$$

Corresponding uncertainty on the d-excess was assessed as $\pm 1.7 \%$. All the data are reported in the Supplementary Materials.

\section{Results}

The results of the $\delta^{18} \mathrm{O}-\delta^{2} \mathrm{H}$ analyses are reported in Table 1. For most springs, the isotopic signature is the mean value, calculated based on different numbers of samples. Four springs (namely: Cadoniche, Borra, Fugazzolo, and La Fontanina) were sampled only once during the recession period and analyzed only with respect to the $\delta^{18} \mathrm{O}$ parameter. With reference to the altitude profile of the northern Apennines of Italy, both the northern and southern isotopic transects (see continuous and dashed black lines in Figure 2) were built starting from the abovementioned mean values of $\delta^{18} \mathrm{O}$, in order to present the isotopic signature evolution along the transects (Figure 4). The springs belonging to the northern transect showed $\delta^{18} \mathrm{O}$ contents ranging between $-9.4 \%$ ond $-5.7 \%$ o and $\delta^{2} \mathrm{H}$ contents ranging between $-65 \%$ and $-36 \%$ (Figure $4 \mathrm{a}, \delta^{2} \mathrm{H}$ values are not shown as being characterized by the same pattern as the $\delta^{18} \mathrm{O}$ content). The corresponding deuterium excess (d-excess) varies between $9.4 \%$ and $15 \%$ o.

The southern transect was characterized by $\delta^{18} \mathrm{O}$ values ranging between $-10.1 \%$ ond $-6.6 \%$ and $\delta^{2} \mathrm{H}$ contents ranging between $-67 \%$ ond $-41 \%$ o (Figure $4 \mathrm{~b}$, as in the case of the northern transect, $\delta^{2} \mathrm{H}$ values are not shown as being characterized by the same pattern as the $\delta{ }^{18} \mathrm{O}$ content). The d-excess varied between $9.2 \%$ and $14.9 \%$. The isotopic contents did not continuously decrease with the altitude, as the most negative values characterize the springs from the eastern sides of both the northern and southern transects. The d-excess ranges of the two groups (northern and southern transects) were practically the same.

Figure 5 presents the box-plots of all the isotopic data collected in this study. Isotopes from the low-yield springs were divided into four groups, namely WSS (western side springs of the southern transect), WSN (western side springs of the northern transect), ES (eastern side springs), and EA (eastern side Adriatic spring). By looking the $\delta^{18} \mathrm{O}$ and $\delta^{2} \mathrm{H}$ data, it is evident that WSN, ES, and EA groups showed a more attenuation of the isotopic signatures when compared with the WSS data (see box limits representing the 25th and 75th percentiles). The mean values of $\delta^{18} \mathrm{O}$ and $\delta^{2} \mathrm{H}$ from the ES ( $-9.5 \%$ ond $-65 \%$, respectively) and EA ( $-9.4 \%$ ond $-63 \%$ ) low-yield springs were slightly more negative than those from the WSN (-6.4\%o and $-39 \%$ o) and WSS $(-7.8 \%$ o and $-53 \%$ o $)$ low-yield springs. Unlike the $\delta^{18} \mathrm{O}$ and $\delta^{2} \mathrm{H}$ values, d-excess data become more scattered in the WSN, ES, and EA groups. Once again, the lowest mean values characterized the ES and EA low-yield springs, at $+11 \%$ o and $+12 \%$ o, respectively. The box-plot diagram shows the types of springs grouped congruently, demonstrating that there was lower isotopic content in the eastern springs compared with the western springs. 
Table 1. Isotopic contents and main properties of the selected springs.

\begin{tabular}{|c|c|c|c|c|c|c|c|c|c|}
\hline No. on Map & $\begin{array}{l}\text { Name of the } \\
\text { Spring }\end{array}$ & $\begin{array}{l}\text { Number } \\
\text { of Values }\end{array}$ & $\begin{array}{l}\text { Emerging } \\
\text { Altitude }\end{array}$ & $\begin{array}{l}\text { Mean Altitude of } \\
\text { the Watershed }\end{array}$ & $\begin{array}{c}\text { Oxygen-18 } \\
\text { (Low Flow Value) }\end{array}$ & $+/-$ & $\begin{array}{c}\text { Deuterium } \\
\text { (Low Flow Value) }\end{array}$ & $+/-$ & d-excess \\
\hline 1 & km 14.6 & 8 & 475 & 700 & -6.58 & 0.16 & -40.6 & & 12.04 \\
\hline 2 & $\mathrm{~km} 29.2$ & 7 & 600 & 800 & -7.54 & 0.05 & -47.4 & 0.23 & 12.92 \\
\hline 3 & $\mathrm{~km} 32.6$ & 6 & 425 & 800 & -7.71 & 0.09 & -49.5 & 0.6 & 12.18 \\
\hline 4 & $\mathrm{~km} 35.4$ & 8 & 370 & 400 & -6.67 & 0.11 & -44.2 & 0.5 & 9.16 \\
\hline 5 & S. francesco & 9 & 490 & 510 & -6.65 & 0.05 & -41.4 & 0.3 & 11.8 \\
\hline 6 & La fredda & 9 & 1540 & 1650 & -8.89 & 0.13 & -56.2 & 0.3 & 14.92 \\
\hline 7 & Imbrancamento & 14 & 1350 & 1480 & -8.69 & 0.26 & -55.3 & 0.7 & 14.22 \\
\hline 8 & Fontana fredda & 17 & 150 & 300 & -5.7 & 0.06 & -36.2 & 0.7 & 9.4 \\
\hline 9 & Maestà & 10 & 800 & 810 & -6.32 & 0.29 & -35.6 & 0.5 & 14.96 \\
\hline 10 & Acqua sparta & 10 & 1275 & 1350 & -6.93 & 0.23 & -43.3 & 0.4 & 12.14 \\
\hline 11 & Secchia springs & 2 & 1500 & 1700 & -8.57 & 0.11 & -56.4 & 0.2 & 12.16 \\
\hline 12 & Cadoniche & 1 & 1325 & 1350 & -9.37 & & & & \\
\hline 13 & Collagna & 7 & 850 & 960 & -8.37 & 0.13 & -53.7 & 1.6 & 13.26 \\
\hline 14 & Mt Cantiere & 8 & 1170 & 1450 & -9.85 & 0.08 & -65.6 & 0.8 & 13.2 \\
\hline 15 & Venano & 7 & 1180 & 1280 & -10.15 & 0.1 & -67.07 & 1.5 & 14.13 \\
\hline 16 & Borra & 1 & 900 & 1100 & -9.71 & & & & \\
\hline 17 & Fugazzolo & 1 & 1017 & 1000 & -8.9 & & & & \\
\hline 18 & Berceto & 13 & 825 & 880 & -8.37 & 0.21 & -53.3 & 0.3 & 13.66 \\
\hline 19 & Montecagno & 22 & 1050 & 1100 & -9.10 & 0.05 & -62.96 & 0.3 & 9.84 \\
\hline 20 & Bismantova & 14 & 800 & 920 & -9.24 & 0.38 & -61.9 & 0.6 & 12.02 \\
\hline 21 & M. di Puianello & 2 & 350 & 375 & -9.00 & 0.18 & -60.2 & 0.4 & 11.8 \\
\hline 22 & Lusino & 7 & 325 & 440 & -9.26 & 0.11 & -64.7 & 0.5 & 9.38 \\
\hline 23 & La fontanina & 1 & 650 & 725 & -9.9 & 0.12 & & & \\
\hline
\end{tabular}



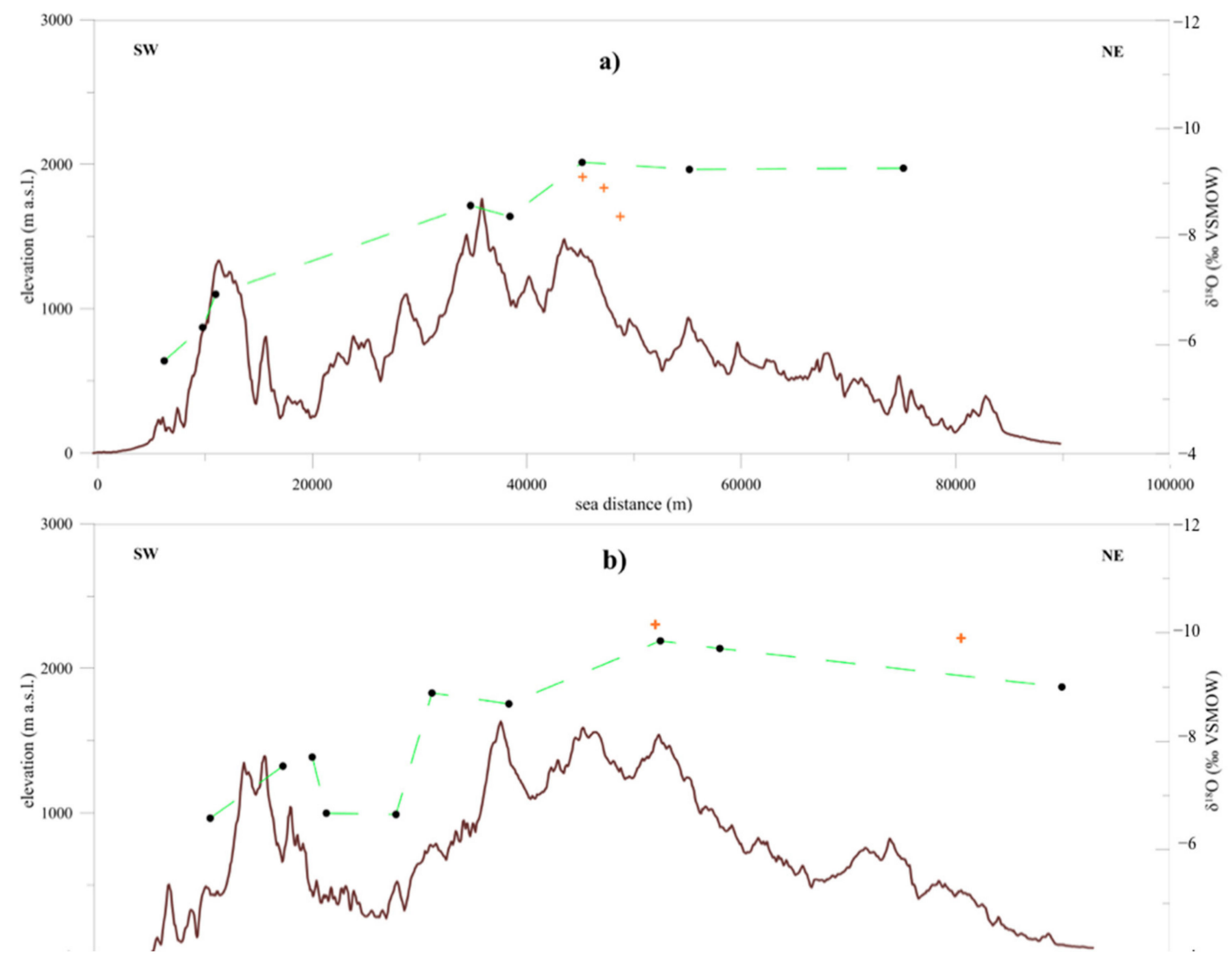

Figure 4. Altitudinal and isotopic profiles concerning the southern (b) and northern (a) transects (trace sections are reported in Figure 2): the dashed line is the isotopic profile; the solid line is the topographic profile. Orange crosses represent the isotopic values of springs not included in the transects (see Figure 2). The y-scale is exaggerated by 2.

We plotted $\delta^{18} \mathrm{O}$ versus $\delta^{2} \mathrm{H}$ (shown in Figure 6), and our samples were near to the Global Meteoric Water Line (GMWL) identified in [10], and close to the local meteoric water line presented in [4] for northern Italy (Northern Italy Meteoric Water Line, NIMWL). Moreover, in the $\delta^{18} \mathrm{O}$ versus $\delta^{2} \mathrm{H}$ plot samples from springs located on the western side of the study area (the Tyrrhenian side) were aligned along a local groundwater line having an equation of:

$$
\delta^{2} \mathrm{H}=6.9 \times \delta^{18} \mathrm{O}+5\left(\mathrm{r}^{2}: 0.95\right) .
$$

Similarly, samples from springs located on the eastern side of the study area (the Po Plain side) were aligned along a local groundwater line having an equation of:

$$
\delta^{2} \mathrm{H}=8.7 \times \delta^{18} \mathrm{O}+19\left(\mathrm{r}^{2}: 0.91\right)
$$

In the study area four different altitude- $\delta^{18} \mathrm{O}$ relationships with different isotopic gradients are calculated (Figure 7). On the western side, the isotopic gradients were very similar in the two transects, $-0.18 \%$ o $/ 100 \mathrm{~m}$, in the northern profile, and $-0.17 \%$ o/ $100 \mathrm{~m}$, in the southern profile. On the contrary, on the eastern side, two very different isotopic gradients occurred, considering respectively the springs of the foothills zones $(-0.25 \% \mathrm{o} / 100 \mathrm{~m})$ and the springs nearer to the main watershed divide of the northern Apennines $(-0.39 \% / 100 \mathrm{~m})$. 


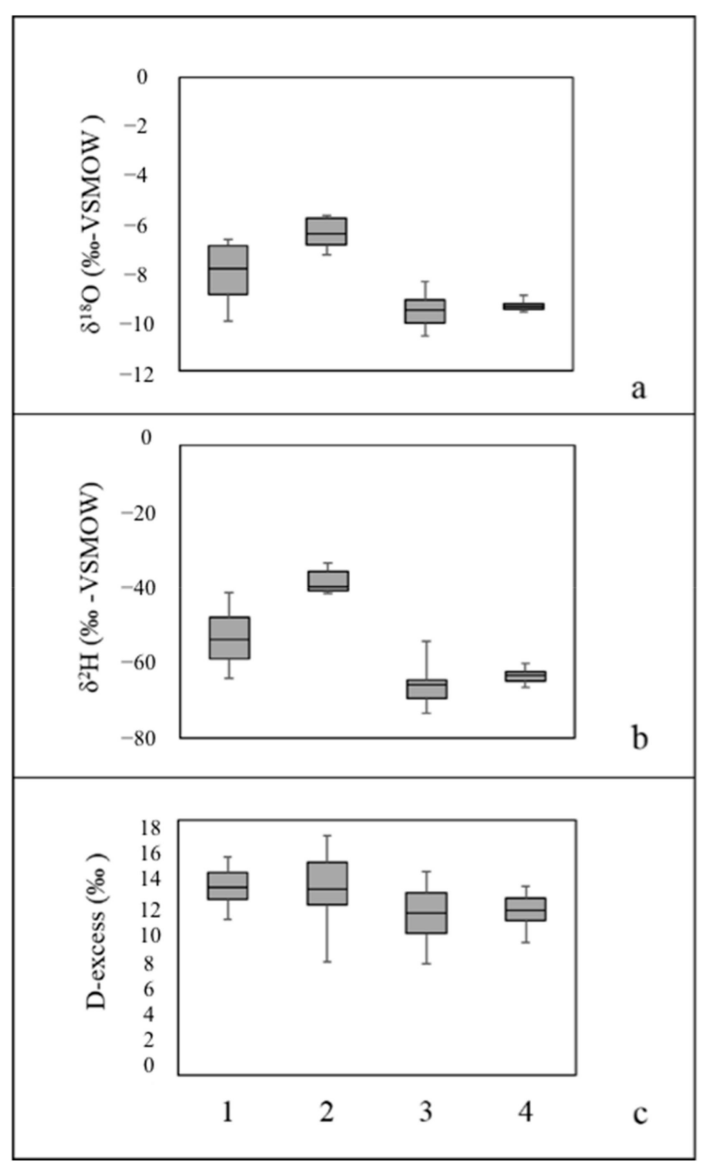

Figure 5. Box plot of (a) $\delta^{18} \mathrm{O},(\mathbf{b}) \delta^{2} \mathrm{H}$, and (c) d-excess for all the groundwater samples grouped into (1) WSS, (2) WSN, (3) ES, (4) EA low-yield springs (see Figure 2 for the location of the springs). The whiskers represent the 10th and 90th percentiles, the box limits indicate the 25th and 75th percentiles and the line within the box marks is the mean values.

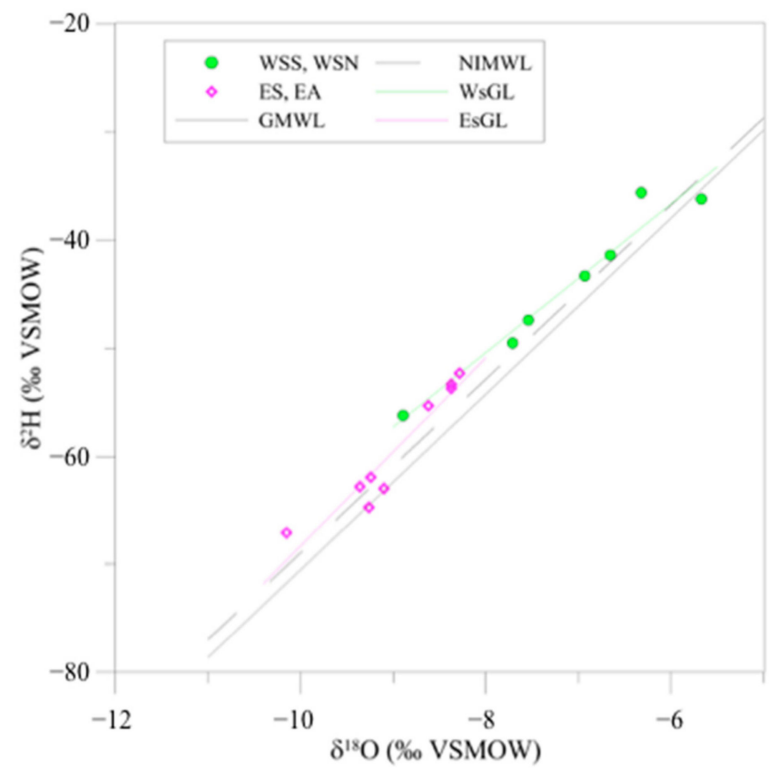

Figure 6. Plot of deuterium versus oxygen-18 for the investigated springs. The global meteoric water line [10] and the Northern Italy water line [4] are also reported. EsGL: Eastern side Groundwater Line; WsGL: Western side Groundwater Line. 


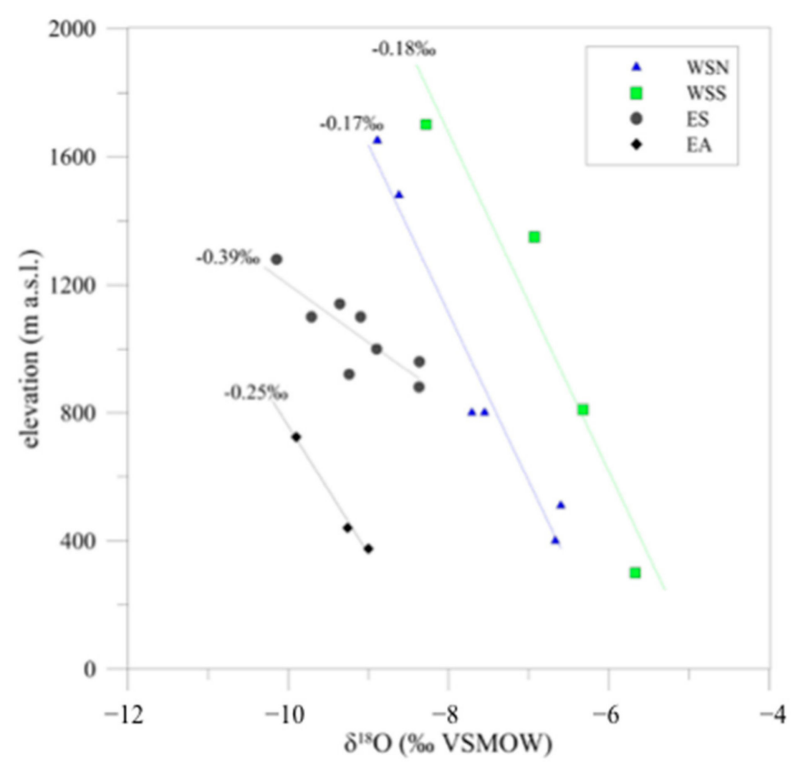

Figure 7. Altitudinal isotopic gradient of the selected springs.

\section{Discussion}

As anticipated in Section 4 (Figure 5), all the isotopic data from the low-yield springs (in particular those from the WSN, ES, and EA groups) were poorly scattered, providing evidence that the groundwater sampled from the recession periods is representative of the mean isotopic recharge. Moreover, the $\delta^{18} \mathrm{O}$ patterns profile follows the topography profile and allowed us to identify specific behavior of these isotopes with respect to the altitude. The eastern side of both the northern and southern transects (i.e., the ES and EA groups) was in fact characterized by the most depleted $\delta^{18} \mathrm{O}$ values. The western side of the northern transect (Figure 4a) showed a progressive decrement of $\delta$ ${ }^{18} \mathrm{O}$ from the Tyrrhenian side to the highest reliefs (from -5.7 to $-9.4 \%$ ), whereas on the eastern side, the isotopic values remained almost constant, on $-9.3 \%$. The low isotopic values found on the eastern side were the result of the shadow effect caused by the Alps chain on the clouds originating from the air masses of central Europe [38], which strongly controlled the precipitation regime of this part of the northern Apennines. On the western side of the southern transect (Figure $4 \mathrm{~b}$ ) $\delta^{18} \mathrm{O}$ decreased from the Tyrrhenian side to the Apuan Alps. There, $\delta^{18} \mathrm{O}$ became progressively more enriched with the decrease of altitude, as a probably result of recharge due to precipitations generated by the air masses inflow from the Tyrrhenian sea into the Serchio valley [55]. Starting from the Serchio valley $\delta^{18} \mathrm{O}$ values abruptly decreased from -6.7 to $-8.9 \%$ o before the main watershed divide, after which the isotopic signal first approached to $-10.0 \%$ and then progressively increased up to $-9.0 \%$. The low isotopic values found on the eastern side for both the transects (EA group) were the results of the above-mentioned shadow effect by the Alps chain on the clouds originating from the air masses of central Europe [38]. The lowest values of $\delta{ }^{18} \mathrm{O}(-9.9 \%$ o) were recorded in a spring discharging at about $1100 \mathrm{~m}$ a.s.l. However, moving toward the Po Plain, the $\delta{ }^{18} \mathrm{O}$ values became more enriched $(-9.0 \%)$ with the decreasing of the altitude.

The $\delta^{18} \mathrm{O} \delta{ }^{2} \mathrm{H}$ plot (Figure 6) points out several differences existing between the two datasets (western side versus eastern side springs): more enriched values were recorded in the springs on the Tyrrhenian side (the western side). The regression lines (EsGL and WsGL in Figure 6) were similar to the GMWL, evidencing that these springs were recharged by precipitation having isotopic contents comparable to the average global isotopic composition and close to the NIMWL for precipitation in northern Italy. Nevertheless, the slope of the WsGL was lower than that of the EsGL (6.9 and 8.7 respectively) almost overlapping with the GMWL. The difference in the isotopic content between the two groups had already been observed in the precipitation values obtained by $[39]$ and $[55,56]$. This means that, in adjacent areas, during winter, the water vapor was mainly of continental origin, 
and the precipitation was characterized by lower isotopic content. In contrast, during summer, the precipitation chiefly originated from air masses of oceanic provenience and showed higher isotopic content. According to [56], the origins of precipitation during the hydrologic year create an opposite oriented orographic effect in the study area, meaning that the windward slope is alternatively located on the Tyrrhenian side (in summer) and on the Adriatic side (in winter). As already reported in Section 2, the summer precipitation did not recharge the springs in the transects; this was particularly true for the WsGL, which was influenced by the leeward slope during the recharge period. The impact of this orographic effect on the isotopic values in this study was confirmed by the springs' d-excess patterns, that was characterized by a decreasing trend (Figure 8) on both the sides, which is consistent to the increase of isotopic signatures. Moreover, the d-excess was on both the sides in the range $9-15 \%$, similar to that observed for an ensemble of springs in a recent study [57] carried on in a catchment of the Apuan Alps. Such range is much more restricted respect to the wide range (4-22\%o) observed in Apuan rainfalls by the same Authors. Hence, d-excess data (Figure 5), consistently to the conclusions of such study, suggested the occurrence of rainfall infiltration mainly in the period November-May, and a negligible recharge of the groundwater systems in the remaining period of the year. It has been observed, moreover, that lower d-excess in the groundwater can be related to partial evaporation effects [56].

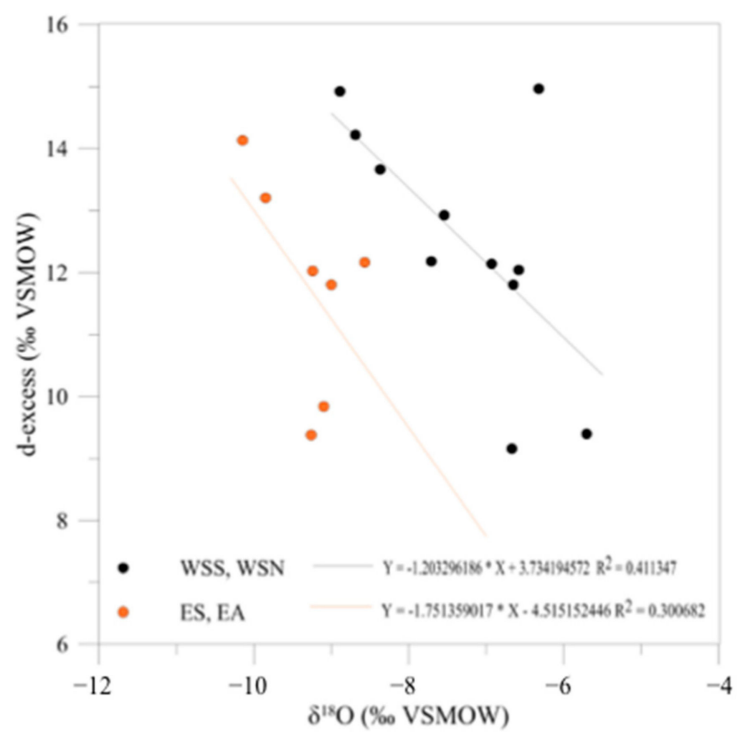

Figure 8. Plot of the deuterium excess versus oxygen-18 for springs belonging to the western (WSS and WSN) and eastern side (ES and EA) of the studied area.

Further considerations concerned the isotopic gradients of the two slopes, calculated using the mean value of the springs' $\delta^{18} \mathrm{O}$ content (Figure 7). As could be expected from the abovementioned leeward slope affecting the Tyrrhenian side during winter, a higher gradient should characterize the Adriatic side. The results show that a higher gradient developed in the eastern side relative to the western side, with values of -0.39 and $-0.17 \%$ o/ $100 \mathrm{~m}$, respectively. In the study area, a few more noteworthy differences were evidenced. On the eastern side, the foothills of the northern Apennines were partly affected by Adriatic-contributed precipitation that leads to a slightly lower gradient $(0.25 \% / 100 \mathrm{~m})$ than that of the upper reliefs on the same side. The lower gradient was in the range of those found in $[27,29,30]$ for precipitation from the Adriatic side. On the western side, the gradients calculated along the two transects (the southern and northern) were similar $(-0.17$ and $-0.18 \% \% / 100 \mathrm{~m}$ respectively) but a shift of about one delta of the $\delta^{18} \mathrm{O}$ values was evident (Figure 7).

These results contribute to our understanding of aquifer recharge areas in mountainous zones characterized by strong variability in precipitation regimes and complex topography. First of all, altitude isotopic gradients using pluviometers and covering very extended areas should not be utilized 
in detailed hydrogeological studies. This is apparent when comparing the gradients obtained in [4,26], which were higher on the Tyrrhenian side and in the central part of the transect and more similar in the vicinity of the Po Plain. Second, a more local scale in these kinds of studies is more advisable with respect to the isotopic content of the groundwater, as marked differences between valleys and slopes (often fewer than a few kilometers apart) were observed here.

\section{Conclusions}

This study demonstrates that stable isotopes of water collected during recession period in low-yield springs can be useful to obtain altitude gradients for hydrogeological studies in mountainous areas. We believe that this is an important point given the increasing application of such isotopes in environmental and engineering studies aimed at determining the recharge areas of springs and groundwater. The analysis of our dataset, however, allowed us to reach several important conclusions with respect to the use of water isotopes from springs. Firstly, in this approach springs must be carefully selected a priori in order to strictly select those with well-known and reduced recharge areas (near the point where the spring flows), in which an almost complete renewal of groundwater takes place every year (i.e., low-yield springs). In the northern Apennines of Italy, these springs usually flow out from fractured rock masses made up of flysch or sandstones, and their discharge patterns closely follow the local meteoric recharge patterns. In such conditions, the recession period is from late summer to early autumn and is characterized by the average isotopic content of the antecedent recharge period occurring during the late autumn, winter, and spring months. As a result, water stable isotopes can only be obtained from samples collected during this recession period. This method is superior to using rain gauges to collect samples for subsequent isotopic analysis. In fact, samples from springs are more suitable for such research than rain data because of the significant influence of evapotranspiration and infiltration processes on surface soil during the recharge period, which usually results in significant discrepancies between the isotopic contents of rain gauges and groundwater.

Secondly, it has been demonstrated that in complex areas such as the northern Apennines of Italy, researchers conducting hydrogeological investigations must be aware that considering a single isotopic gradient for the whole mountainous chain may result in significant errors in the final assessment of the mean altitude of recharge of the groundwater. In fact, in the northern Apennines of Italy altitude gradients of ${ }^{18} \mathrm{O}$ varied from $-0.17 \% / 100 \mathrm{~m}$ (ES) to $-0.39 \% \mathrm{o} / 100 \mathrm{~m}$ (EAS) depending mainly on the topographic effect (windward/leeward side with reference to the direction of the air masses) and the origin (oceanic or continental) of the precipitation in the area. This means that altitude gradients obtained from stable isotopes of water may differ even in nearby valleys. Thus, based on our results, we suggest that researchers conducting hydrogeological studies requiring estimates of the recharge areas of specific groundwater use a "local scale" approach consisting of low-yield springs located in the same valley (or slope) of the groundwater under investigation.

Future studies, involving both the meteoric waters and groundwater of a few low-yield springs in the northern Apennines of Italy have already been planned and will begin soon. This research will allow us to better understand the hydrological processes taking place during the recharge period and to quantify the mechanisms of evapotranspiration, runoff, and infiltration controlling the isotopic differentiation between rain gauges and groundwater.

Supplementary Materials: The following are available online at http://www.mdpi.com/2073-4441/11/9/1764/s1, Excel file with data: manuscript-supplementary.xlsx.

Author Contributions: All the authors contributed to the conception of the study. M.M., F.R., A.T. acquired the data. A.T., F.C. contributed significantly to write the manuscript. M.D., F.R., M.D. helped to revise the manuscript. M.D., A.T., M.M. and F.C. analyze the data. M.M. conducted the laboratory analyses.

Funding: This research received no external funding.

Acknowledgments: Authors would like to thank two anonymous reviewers for their precious and constructive remarks that allowed the manuscript to be greatly improved.

Conflicts of Interest: The authors declare no conflict of interest. 


\section{References}

1. Rozanski, K.; Sonntag, C. Vertical distribution of deuterium in atmospheric water vapour. Tellus 1982, 34, 135-141. [CrossRef]

2. Nanni, T.; Tazioli, A.; Vivalda, P. Problems in the application of environmental isotopes to the hydrogeology of high mountain aquifers. Aqua Mundi 2013, 4, 55-66.

3. Schemmel, F.; Mikes, T.; Rojay, B.; Mulch, A. The impact of topography on isotopes in precipitation across the Central Anatolian Plateau (Turkey). Am. J. Sci. 2013, 313, 61-80. [CrossRef]

4. Giustini, F.; Brilli, M.; Patera, A. Mapping oxygen stable isotopes of precipitation in Italy. J. Hydrol. Reg. Stud. 2016, 8, 162-181. [CrossRef]

5. Le Duy, N.; Heidbüchel, I.; Meyer, H.; Merz, B.; Apel, H. What controls the stable isotope composition of precipitation in the Mekong Delta? A model-based statistical approach. Hydrol. Earth Syst. Sci. 2018, 22, 1239-1262. [CrossRef]

6. Clark, I.D.; Fritz, P. Environmental Isotopes in Hydrogeology; CRC Press: Boca Raton, FL, USA, 2013; ISBN 978-1-4822-4291-1.

7. Gat, J.R.; Carmi, I. Evolution of the isotopic composition of atmospheric waters in the Mediterranean Sea area. J. Geophys. Res. 1970, 75, 3039-3048. [CrossRef]

8. Gonfiantini, R. Chapter 3-Environmental isotopes in lake studies. In The Terrestrial Environment, $B$; Handbook of Environmental Isotope Geochemistry; Fritz, P., Fontes, J.C., Eds.; Elsevier: Amsterdam, The Netherlands, 1986; pp. 113-168, ISBN 978-0-444-42225-5.

9. Craig, H. Isotopic Variations in Meteoric Waters. Science 1961, 133, 1702-1703. [CrossRef] [PubMed]

10. Rozanski, K.; Araguás-Araguá, L.; Gonfiantini, R. Isotopic Patterns in Modern Global Precipitation. In Climate Change in Continental Isotopic Records; Swart, P.K., Lohmann, K.C., McKenzie, J., Savin, S., Eds.; American Geophysical Union (AGU): Washington, DC, USA, 1993; pp. 1-36, ISBN 978-1-118-66402-5.

11. McGuire, K.; Mcdonnell, J. Stable Isotope Tracers in Watershed Hydrology. In Stable Isotopes in Ecology and Environmental Science, 2nd ed.; Blackwell Publishing: Malden, MA, USA, 2008; pp. 334-374, ISBN 978-0-470-69185-4.

12. Doveri, M.; Menichini, M.; Cerrina Feroni, A. Gli isotopi stabili dell'acqua come strumento fondamentale nello studio degli acquiferi carsici: Alcuni esempi di applicazione sui complessi carbonatici delle Alpi Apuane (Toscana nw)-Stable water isotope sas fundamental tool in karst aquifer sudies: some results from isotopic applications in the Apuan Alps carbonatic complexes (NW Tuscany, Italy)_IJEGE. Ital. J. Eng. Geol. Environ. 2013, 13, 33-50.

13. Doveri, M.; Menichini, M.; Scozzari, A. Protection of Groundwater Resources: Worldwide Regulations and Scientific Approaches. In Threats to the Quality of Groundwater Resources: Prevention and Control (The Handbook of Environmental Chemistry); Scozzari, A., Dotsika, E., Eds.; Springer: Berlin/Heidelberg, Germany, 2016; pp. 13-30. ISBN 978-3-662-48596-5.

14. Montanari, D.; Minissale, A.; Doveri, M.; Gola, G.; Trumpy, E.; Santilano, A.; Manzella, A. Geothermal resources within carbonate reservoirs in western Sicily (Italy): A review. Earth Sci. Rev. 2017, 169, 180-201. [CrossRef]

15. Tazioli, A. Does the recharge area of a Spring Vary from year to year? Information from the water isotopes. Ital. J. Eng. Geol. Environ. 2017, 2017, 41-56.

16. Dansgaard, W. Stable isotopes in precipitation. Tellus 1964, 16, 436-468. [CrossRef]

17. Wassenaar, L.I.; Hendry, M.J.; Chostner, V.L.; Lis, G.P. High Resolution Pore Water $\delta 2 \mathrm{H}$ and $\delta 18 \mathrm{O}$ Measurements by $\mathrm{H}_{2} \mathrm{O}$ (liquid) $-\mathrm{H}_{2} \mathrm{O}$ (vapor) Equilibration Laser Spectroscopy. Environ. Sci. Technol. 2008, 42, 9262-9267. [CrossRef] [PubMed]

18. Hendry, M.J.; Wassenaar, L.I. Inferring Heterogeneity in Aquitards Using High-Resolution $\delta \mathrm{D}$ and $\delta 18 \mathrm{O}$ Profiles. Groundwater 2009, 47, 639-645. [CrossRef] [PubMed]

19. Stumpp, C.; Hendry, M.J. Spatial and temporal dynamics of water flow and solute transport in a heterogeneous glacial till: The application of high-resolution profiles of $\delta 18 \mathrm{O}$ and $\delta 2 \mathrm{H}$ in pore waters. J. Hydrol. 2012, 438, 203-214. [CrossRef]

20. Mussi, M.; Nanni, T.; Tazioli, A.; Vivalda, P.M. The Mt Conero limestone ridge: The contribution of stable isotopes to the identification of the recharge area of aquifers. Ital. J. Geosci. 2017, 136, 186-197. [CrossRef]

21. Gat, J.R. Oxygen and hydrogen isotopes in the hydrologic cycle. Annu. Rev. Earth Planet. Sci. 1996, 24, 225-262. [CrossRef] 
22. Doveri, M.; Mussi, M. Water Isotopes as Environmental Tracers for Conceptual Understanding of Groundwater Flow: An Application for Fractured Aquifer Systems in the "Scansano-Magliano in Toscana" Area (Southern Tuscany, Italy). Water 2014, 6, 2255-2277. [CrossRef]

23. Cervi, F.; Corsini, A.; Doveri, M.; Mussi, M.; Ronchetti, F.; Tazioli, A. Characterizing the recharge of fractured aquifers: A case study in a flysch rock mass of the northern apennines (italy). In Engineering Geology for Society and Territory_Volume 3: River Basins, Reservoir Sedimentation and Water Resources; Springer, Cham: Basel, Switzerland, 2015; pp. 563-567.

24. Vespasiano, G.; Apollaro, C.; De Rosa, R.; Muto, F.; Larosa, S.; Fiebig, J.; Mulch, A.; Marini, L. The Small Spring Method (SSM) for the definition of stable isotope-Elevation relationships in Northern Calabria (Southern Italy). Appl. Geochem. 2015, 63, 333-346. [CrossRef]

25. Deiana, M.; Cervi, F.; Pennisi, M.; Mussi, M.; Bertrand, C.; Tazioli, A.; Corsini, A.; Ronchetti, F. Chemical and isotopic investigations $(\delta 18 \mathrm{O}, \delta 2 \mathrm{H}, 3 \mathrm{H}, 87 \mathrm{Sr} / 86 \mathrm{Sr})$ to define groundwater processes occurring in a deep-seated landslide in flysch. Hydrogeol. J. 2018, 26, 2669-2691. [CrossRef]

26. Longinelli, A.; Selmo, E. Isotopic composition of precipitation in Italy: A first overall map. J. Hydrol. 2003, 270, 75-88.

27. Zuppi, G.M.; Fontes, J.C.; Letolle, R. Isotopes du milieu et circolations d'eaux sulfureès dans le Latium. In Proceedings of the Isot. Techn. in Groundwater Hydrology; IAEA: Vienna, Austria, 1974; Volume 1, pp. 341-361.

28. Barbieri, M.; Boschetti, T.; Petitta, M.; Tallini, M. Stable isotope (2H, $18 \mathrm{O}$ and $87 \mathrm{Sr} / 86 \mathrm{Sr})$ and hydrochemistry monitoring for groundwater hydrodynamics analysis in a karst aquifer (Gran Sasso, Central Italy). Appl. Geochem. 2005, 20, 2063-2081. [CrossRef]

29. Conversini, P.; Tazioli, G.S. Indagini idrogeologiche nella media e alta valle del fiume Menotre, Umbria orientale. Atti Tic. Sci. Terra 1993, 36, 153-164.

30. Tazioli, A.; Mosca, M.; Tazioli, G.S. Location of recharge area of Gorgovivo Spring, Central Italy. A contribution from isotope hydrology. In Proceedings of the International Symposium "Advances in Isotope Hydrology and Its Role in Sustainable Water Resources Management (IHS-2007)"; IAEA: Vienna, Austria, 2007; pp. 27-35.

31. Tazioli, A.; Conversini, P.; Peccerillo, A. Hydrogeological and geochemical characterisation of the Rock of Orvieto. Environ. Earth Sci. 2012, 66, 55-65. [CrossRef]

32. Deiana, M.; Mussi, M.; Ronchetti, F. Discharge and environmental isotope behaviours of adjacent fractured and porous aquifers. Environ. Earth Sci. 2017, 76, 595. [CrossRef]

33. Cervi, F.; Ronchetti, F.; Doveri, M.; Mussi, M.; Marcaccio, M.; Tazioli, A. The use of stable water isotopes from rain gauges network to define the recharge areas of springs: Problems and possible solutions from case studies in the northern Apennines. Geoing. Ambient. Min. 2016, 149, 19-26.

34. Molli, G. Northern Apennine-Corsica orogenic system: An updated overview. Geol. Soc. Lond. Spec. Publ. 2008, 298, 413-442. [CrossRef]

35. Civita, M.; Forti, P.; Marini, P.; Meccheri, M.; Micheli, L.; Piccini, L.; Pranzini, G. Note Illustrative Della Carta Della Vulnerabilità All'inquinamento Degli Acquiferi Delle Alpi Apuane_Pollution Vulnerability Map for the Aquifers of the Apuane Alps a Brief Guide; SELCA: Firenze, Italy, 1991.

36. Baldacci, F.; Cecchini, S.; Lopane, G.; Raggi, G. Le risorse idriche del bacino del Fiume Serchio ed il loro contributo all'alimentazione dei bacini idrografici adiacenti. Mem. Della Soc. Geol. Ital. 1993, 49, 365-391.

37. Antolini, G.; Pavan, V.; Tomozeiu, R.; Marletto, V. Atlante climatico dell'Emilia-Romagna. Casma Tipolito srl-Bologna, Italy, 1961-2015. Available online: https://www.arpae.it/cms3/documenti/_cerca_doc/meteo/ clima/Atlante_climatico_1961-2015.pdf (accessed on 23 August 2019).

38. Longinelli, A.; Anglesio, E.; Flora, O.; Iacumin, P.; Selmo, E. Isotopic composition of precipitation in Northern Italy: Reverse effect of anomalous climatic events. J. Hydrol. 2006, 329, 471-476. [CrossRef]

39. Zuppi, G.M.; Bortolami, G. Hydrogeology: A privileged field for environmental stable isotopes applications. Some Italian examples. Rend. Della Soc. Ital. Mineral. Petrol. 1983, 38, 1197-1212.

40. Boccaletti, M.; Elter, P.; Guazzone, G. Polarita strutturali delle Alpi e dell'Appennino settentrionale in rapporto all'inversione di una zona di subduzione nord-tirrenica. Mem. Della Soc. Geol. Ital. 1971, 10, 371-378.

41. Carmignani, L.; Kligfield, R. Crustal extension in the Northern Apennines: The transition from compression to extension in the Alpi Apuane Core Complex. Tectonics 1990, 9, 1275-1303. [CrossRef]

42. Molli, G.; Cortecci, G.; Vaselli, L.; Ottria, G.; Cortopassi, A.; Dinelli, E.; Mussi, M.; Barbieri, M. Fault zone structure and fluid-Rock interaction of a high angle normal fault in Carrara marble (NW Tuscany, Italy). J. Struct. Geol. 2010, 32, 1334-1348. [CrossRef] 
43. Corsini, A.; Cervi, F.; Ronchetti, F. Weight of evidence and artificial neural networks for potential groundwater spring mapping: An application to the Mt. Modino area (Northern Apennines, Italy). Geomorphology 2009, 111, 79-87. [CrossRef]

44. Gargini, A.; De Nardo, M.T.; Piccinini, L.; Segadelli, S.; Vincenzi, V. Spring discharge and groundwater flow systems in sedimentary and ophiolitic hard rock aquifers: Experiences from Northern Apennines (Italy). In Fractured Rock Hydrogeology; IAH—Selected Papers on Hydrogeology; Sharp, J.M., Ed.; CRC Press: Boca Raton, FL, USA, 2014; pp. 129-145, ISBN 978-1-138-00159-6.

45. Molli, G.; Doveri, M.; Manzella, A.; Bonini, L.; Botti, F.; Menichini, M.; Montanari, D.; Trumpy, E.; Ungari, A.; Vaselli, L. Surface-subsurface structural architecture and groundwater flow of the Equi Terme hydrothermal area, northern Tuscany Italy. Ital. J. Geosci. 2015, 134, 442-457. [CrossRef]

46. Doveri, M.; Piccini, L.; Menichini, M. Hydrodynamic and Geochemical Features of Metamorphic Carbonate Aquifers and Implications for Water Management: The Apuan Alps (NW Tuscany, Italy) Case Study. In Karst Water Environment; The handbook of environmental chemistry; Younos, T., Schreiber, M., Kosič Ficco, C., Eds.; Springer, Cham: Basel, Switzerland, 2019; ISBN 978-3-319-77368-1.

47. Chiesi, M.; De Waele, J.; Forti, P. Origin and evolution of a salty gypsum/anhydrite karst spring: The case of Poiano (Northern Apennines, Italy). Hydrogeol. J. 2010, 18, 1111-1124. [CrossRef]

48. Gargini, A.; Vincenzi, V.; Piccinini, L.; Zuppi, G.M.; Canuti, P. Groundwater flow systems in turbidites of the Northern Apennines (Italy): Natural discharge and high speed railway tunnel drainage. Hydrogeol. J. 2008, 16, 1577-1599. [CrossRef]

49. Cervi, F.; Borgatti, L.; Dreossi, G.; Marcato, G.; Michelini, M.; Stenni, B. Isotopic features of precipitation and groundwater from the Eastern Alps of Italy: Results from the Mt. Tinisa hydrogeological system. Environ. Earth Sci. 2017, 76, 410. [CrossRef]

50. Ronchetti, F.; Borgatti, L.; Cervi, F.; Gorgoni, C.; Piccinini, L.; Vincenzi, V.; Corsini, A. Groundwater processes in a complex landslide, northern Apennines, Italy. Nat. Hazards Earth Syst. Sci. 2009, 9, 895-904. [CrossRef]

51. Freeze, R.A.; Cherry, J.A. Groundwater; Prentice-Hall: Englewood cliffs, NJ, USA, 1979; ISBN 978-0-13-365312-0.

52. Cervi, F.; Borgatti, L.; Martinelli, G.; Ronchetti, F. Evidence of deep-water inflow in a tectonic window of the northern Apennines (Italy). Environ. Earth Sci. 2014, 72, 2389-2409. [CrossRef]

53. Epstein, S.; Mayeda, T. Variation of O18 content of waters from natural sources. Geochim. Cosmochim. Acta 1953, 4, 213-224. [CrossRef]

54. Coleman, M.L.; Shepherd, T.; Durham, J.J.; Rouse, J.E.; Moore, G.R. Reduction of water with zinc for hydrogen isotope analysis. Anal. Chem. 1982, 54, 993-995. [CrossRef]

55. Mussi, M.; Leone, G.; Nardi, I. Isotopic geochemistry of natural waters from the Alpi Apuane-Garfagnana area, Northern Tuscany, Italy. Mineral. Petrogr. Acta 1998, 41, 163-178.

56. Guan, H.; Simmons, C.T.; Love, A.J. Orographic controls on rain water isotope distribution in the Mount Lofty Ranges of South Australia. J. Hydrol. 2009, 374, 255-264. [CrossRef]

57. Doveri, M.; Stenni, B.; Petrini, R.; Giannecchini, R.; Dreossi, G.; Menichini, M.; Ghezzi, L. Oxygen and hydrogen isotopic composition of waters in a past-mining area of southern Apuan Alps (Italy): Hydrogeological characterization and implications on the fate of potentially toxic elements. J. Geochem. Explor. 2019, 205, 106338. [CrossRef]

(C) 2019 by the authors. Licensee MDPI, Basel, Switzerland. This article is an open access article distributed under the terms and conditions of the Creative Commons Attribution (CC BY) license (http://creativecommons.org/licenses/by/4.0/). 